\title{
УДК:635.21:632.93:57.084 https://doi.org/10.53040/gppb7.2021.79 \\ ОПРЕДЕЛЕНИЕ УСТОЙЧИВОСТИ КАРТОФЕЛЯ К БУРОЙ БАКТЕРИАЛЬНОЙ ГНИЛИ В ЛАБОРАТОРНЫХ УСЛОВИЯХ
}

\author{
Крым Инесса \\ Украинская научно-исследовательская станции карантина растений Института защиты расте- \\ ний Национальной Академии Аграрных Наук Украины, Черновиџкая обл., Новоселицкий р-н, с. Бо- \\ яны, Украина \\ e-mail: inessakrymnauk@gmail.com
}

\begin{abstract}
The resistance (sensibility) study of potato plant's aboveground part to brown rot causative agent conducted in laboratory conditions. The used technique for infecting plants growing on artificial substrate allowed to standardize experiment conducting and to decrease the hazard of pathogen spread. The received data in such way may use in breeding for the search of resistant parents forms to disease.
\end{abstract}

Key words: potato varieties, brown rot, Ralstonia solanacearum, susceptibility, resistance

\section{Введение}

В настоящее время в промышленном производстве картофеля используется большое количество сортов, устойчивость которых к возбудителю бурой бактериальной гнили картофеля (Ralstonia solanacearum) недостаточно изучена. Это может привести к существенным потерям урожая, поскольку природные условия Украины благоприятны для развития болезни и выживания ее возбудителя, а само заболевание отличается высокой вредоносностью по отношению ко всем пасленовым культурам (картофель, томаты, баклажан, перец); резерваторами инфекции могут быть сорняки, такие как паслен сладко-горький и паслен черный. Также велик риск распространения патогена с посадочным материалом из стран, где обнаружены очаги заболевания $[1,2]$.

Решением проблемы может быть поиск устойчивых к заболеванию сортов с последующим использованием их в селекции на устойчивость. В странах, которые уже столкнулись с этой проблемой, работа по их выведению является частью стратегии по уменьшению убытков и потерь урожая, вызванных бурой бактериальной гнилью. При этом поиск доноров устойчивости в первую очередь проводился среди диких видов и форм картофеля, в частности Solanum demissum и $S$. phureja, на основе которых уже получены достаточно устойчивые сорта, также в селекционной работе используется вид Solanum commersonii [3-6].

Для поиска доноров устойчивости среди уже существующих сортов необходим способ оценки, который позволяет не только получить достоверные результаты в стандартизированных легко воспроизводимых условиях, но и ограничивает риск распространения патогена. Таким образом, целью данной работы был подбор соответствующей методики и ее испытание с использованием сортов картофеля, распространенных в Украине, а также завезенных из других стран для промышленного выращивания либо применения в селекции.

\section{Материалы и методы}

Для изучения уровня устойчивости (восприимчивости) к бурой бактериальной гнили использовали образцы сортов картофеля разного происхождения, полученные от Института картофелеводства, а также Института экспертизы сортов. Исследования проводили в лаборатории карантинных болезней и вредителей УкрНДСКР.

Растения для экспериментов получали путем укоренения отделенных от клубней ростков на искусственном субстрате (перлит) с подкормкой раствором Кнопа [7].

С целью изучения поражения надземной части картофеля стебель растений инокулировали бактериальной суспензией при помощи шприца с гиподермальной иглой. Для приготовления суспензии использовали двухсуточную культуру бактерий Ralstonia solanacearum, выращенных на среде Кинга (штаммы Rs9080 и Rs9081 из коллекции Института микробиологии и вирусологии), 
патогенность бактерий проверяли путем заражения индикаторных растений (сеянцы паслена черного). Контрольным растениям вводили стерильную воду.

Учет проводили трижды (с трехдневным интервалом), оценивая уровень поражения в соответствии со шкалой:

0 - поражение отсутствует

1 - повреждено до $10 \%$ растительных тканей

2 - повреждено 11-25\%

3 - повреждено $26-50 \%$

4 - повреждено более $50 \%$.

Обычно такая шкала применяется для определения развития болезней в полевых условиях, однако ее использование в лабораторных исследованиях оправдано удобством сравнения результатов [8].

После завершения исследований использованный субстрат и остатки растительного материала обеззараживали автоклавированием.

\section{Результаты и обсуждение}

Перед проращиванием образцы клубней были проверены на отсутствие симптомов и возбудителей грибных и бактериальных заболеваний и обеззаражены 1\%-ным раствором гипохлорита натрия с последующим промыванием стерильной водой, после чего их содержали в освещенном помещении при температуре около $18^{\circ} \mathrm{C}$ до образования ростков длиной до 2-3 см, полученные ростки также проверяли на отсутствие поражения болезнями (фитофтороз, черная ножка) и отделяли от клубней для укоренения в контейнерах с простерилизованным перлитом. Из укоренившихся ростков отбирали растения с хорошо сформировавшейся корневой системой и пересаживали в отдельные емкости поштучно для доращивания.

После разворачивания пятого-шестого листа были отобраны здоровые хорошо развитые растения, которые инокулировали бактериальной суспензией и содержали в отдельном (изолированном) помещении при температуре около $24^{\circ} \mathrm{C}$, наблюдая за развитием поражения надземной части. При этом происходило постепенное увядание растений вследствие нарушения водного транспорта по сосудам, пораженным патогеном. По мере развития заболевания листья растений увядали, изменяя цвет от бледно-зеленого до буроватого или бронзового, сморщивались и постепенно отмирали. Стебель вдоль сосудистых пучков становился коричневого цвета, поражение постепенно распространялось от места инокуляции, приводя к гибели растения или значительному замедлению его роста и развития.

В результате проведенных исследований среди изученных образцов не было выявлено сортов с достаточной для использования в селекционной работе устойчивостью к бурой бактериальной гнили, так как у большинства из них уровень поражения достигал 3-4 баллов (табл. 1). Быстрое развитие болезни наблюдалось у сортов Кристал, Мирослава, Ривьера и Цыганка. Наименее поражены оказались сорта Кобза, Лугивська, Полиське Джерело, Спокуса и Фавор, также отмечено, что проявление симптомов поражения у сортов Кристина и Спокуса происходило позже, чем у других образцов.

Использованный способ выращивания опытных растений на искусственном субстрате с подкормкой питательными растворами имеет ряд преимуществ по сравнению с традиционными. В первую очередь, он позволяет получить достаточное количество качественного растительного материала для исследований, придерживаться стандартных условий закладки опытов, что обеспечивает достоверность и воспроизводимость полученных результатов, а также снижает затраты на обеззараживание и утилизацию отходов после завершения эксперимента. Перлит в качестве субстрата можно применять и для выращивания других пасленовых культур (томат, перец) при изучении их устойчивости к бурой бактериальной гнили и другим заболеваниям. 
Таблица 1. Результаты определения уровня поражения надземной части сортов картофеля (2016-2018 гг.)

\begin{tabular}{|c|c|c|c|c|c|c|c|c|c|c|}
\hline \multirow{3}{*}{$\begin{array}{c}\text { № } \\
\Pi / \Pi\end{array}$} & \multirow[t]{3}{*}{ Название сорта } & \multicolumn{9}{|c|}{ Штамм бактерий } \\
\hline & & \multicolumn{3}{|c|}{9080} & \multicolumn{3}{|c|}{9081} & \multicolumn{3}{|c|}{$9080+9081$} \\
\hline & & I & II & III & I & II & III & I & II & III \\
\hline 1 & 2 & 3 & 4 & 5 & 6 & 7 & 8 & 9 & 10 & 11 \\
\hline \multicolumn{11}{|c|}{2016 г. } \\
\hline 1 & Калиновская & - & - & - & 1 & 2 & 3 & $1-2$ & 3 & $3-4$ \\
\hline 2 & Кобза & - & - & - & $1-2$ & $2-3$ & 3 & $1-2$ & 3 & 3 \\
\hline 3 & Невская & - & - & - & $1-2$ & 3 & $3-4$ & 2 & 3 & 4 \\
\hline 4 & Пировська & - & - & - & $1-2$ & 3 & $3-4$ & $1-2$ & 3 & 4 \\
\hline 5 & Полиське джерело & - & - & - & $0-1$ & $1-2$ & 3 & 1 & 2 & 3 \\
\hline 6 & Фактор & - & - & - & $1-2$ & 3 & $3-4$ & $1-2$ & 3 & 4 \\
\hline \multicolumn{11}{|c|}{$2017 \Gamma}$. \\
\hline 7 & Агата & 2 & 3 & 4 & 2 & $2-3$ & $3-4$ & 2 & $3-4$ & 4 \\
\hline 8 & Глазурна & 2 & 3 & $3-4$ & 2 & $2-3$ & $3-4$ & 2 & 3 & $3-4$ \\
\hline 9 & Кристина & $1-2$ & 2 & 3 & 2 & $2-3$ & $3-4$ & $1-2$ & 2 & 3 \\
\hline 10 & Криспер & 2 & 3 & $3-4$ & 2 & $2-3$ & 4 & 2 & 3 & $3-4$ \\
\hline 11 & Мирослава & 2 & 3 & $3-4$ & 2 & 3 & 4 & 2 & 3 & 4 \\
\hline 12 & Ривьера & 2 & 3 & 4 & 2 & $2-3$ & $3-4$ & 2 & 3 & $3-4$ \\
\hline 13 & Тайфун & 2 & 3 & $3-4$ & 2 & 3 & 3 & 2 & 3 & $3-4$ \\
\hline 14 & Тетерив & 2 & 3 & $3-4$ & 2 & $2-3$ & $3-4$ & 2 & $2-3$ & $3-4$ \\
\hline 15 & Фавор & $1-2$ & 2 & 3 & $1-2$ & 3 & $3-4$ & $1-2$ & $2-3$ & 3 \\
\hline 16 & Хортица & 2 & $2-3$ & 3 & $1-2$ & $2-3$ & 3 & 2 & 3 & $3-4$ \\
\hline \multicolumn{11}{|c|}{2018 г. } \\
\hline 17 & Багряна & 2 & 3 & $3-4$ & - & - & - & 2 & 3 & 4 \\
\hline 18 & Барильчиха & - & - & - & - & - & - & 2 & 3 & 3 \\
\hline 19 & Калиновская & $1-2$ & 2 & 3 & - & - & - & 2 & $2-3$ & 3 \\
\hline 20 & Кристал & - & - & - & - & - & - & $2-3$ & 3 & 4 \\
\hline 21 & Лугивська & $1-2$ & 2 & $2-3$ & - & - & - & $1-2$ & 2 & 3 \\
\hline 22 & Пировська & 2 & 2 & 3 & - & - & - & 2 & $2-3$ & 3 \\
\hline 23 & Подолия & 2 & $2-3$ & 3 & 2 & 3 & $3-4$ & 2 & 3 & 3 \\
\hline 24 & Ривьера & 2 & 3 & 4 & - & - & - & 2 & $3-4$ & 4 \\
\hline 25 & Словянка & $1-2$ & 2 & 3 & 2 & $2-3$ & 3 & 2 & $2-3$ & 3 \\
\hline 26 & Спокуса & $0-1$ & 2 & $2-3$ & $0-1$ & $1-2$ & $2-3$ & 1 & $1-2$ & 3 \\
\hline 27 & Тирас & 2 & 3 & $3-4$ & 2 & $2-3$ & $3-4$ & 2 & 3 & 4 \\
\hline 28 & Фавор & 1 & $1-2$ & 3 & 1 & 2 & 3 & 1 & 2 & 3 \\
\hline 29 & Цыганка & 2 & 3 & 4 & - & - & - & $2-3$ & $3-4$ & 4 \\
\hline
\end{tabular}

Примечание: римскими цифрами обозначены 1-й, 2-й и 3-й учет поражения образцов

\section{Выводы}

Среди изученных сортов картофеля не выявлено образцов с достаточной для использования в селекции устойчивостью, поэтому в дальнейших исследованиях будет целесообразным учитывать происхождение каждого сорта, в том числе степень его родства с дикими видами.

Использованная методика позволяет провести проверку устойчивости сортов картофеля в контролируемых лабораторных условиях, что не только снижает затраты на проведение исследований, но и уменьшает риск утечки патогена в окружающую среду.

\section{Литература}

1. Quarantine pests of Europe. Data sheets on quarantine pests for the European Union and for the European and Mediterranean Plant Protection Organization // CAB International. - 1997. - pp. 1071-1081. 
2. JANCE J. Potato Brown rot in western Europe - history, present occurrence and some remarks on possible origin, epidemiology and control strategies / J. Jance // Bulletin OEPP/EPPO. - 1996. - № 26. - p. 679-695.

3. FRENCH, E. R. Multiple disease resistance in potato cultivars with Solanum phureja and S. demissum background / E. R. French // Phytopathology. - 1985. - № 75. - p. 1288.

4. LAFERRIERE, L. T. Fertile Solanum tuberosum+S.commerssoni somatic hybrids as sources of resistance to bacterial wilt caused by R. Solanacearum / L. T. Laferriere, J. P. Helgeson and C. Allen // Theoretical and Applied Genetics. - 1999. - 98. - p. 1272-1278.

5. Resistance to Ralstonia solanacearum of sexual hybrids between Solanum commersonii and Solanum tuberosum / D. Carputo, R. Aversano, A. Barone, A. Di Matteo, M. Iorizzo, L. Sigillo, A. Zoina, L. Fusciante // American Journal of Potato Research. - 2009. - vol. 86, № 3. - p. 196-202.

6. THURSTON, H. D. Resistance to bacterial wilt of potatoes in Colombian clones of Solanum phureja / H. D. Thurston, J. C. Lozano // American Potato Journal. - 1968. - 45. - p. 51-55.

7. КРИМ, І. В., ЗЕЛЯ, А. Г. Методика визначення стійкості картоплі до збудника бурої бактеріальної гнилі картоплі Ralstonia solanacearum (Smith) в лабораторних умовах / I. В. Крим, А. Г. Зеля. Чернівці: «Місто», 2016. - 16 с.

8. ДЕМЕНТЬЕВА, М. И. Фитопатология / М. И. Дементьева. - М.: Колос, 1970. - 464 с. 